\title{
Pengembangan Instrumen Pengukur Kualitas Pelayanan Kesehatan berdasar atas Harapan Peserta Jaminan Kesehatan Nasional di Rumah Sakit
}

\author{
Ida Hadiyati, ${ }^{1}$ Nanan Sekarwana, ${ }^{2}$ Deni Kurniadi Sunjaya, ${ }^{3}$ Elsa Pudji Setiawati ${ }^{3}$ \\ ${ }^{1}$ Dinas Kesehatan Kabupaten Bandung, ${ }^{2}$ Departemen Ilmu Kesehatan Anak, Fakultas Kedokteran, Universitas \\ Padjadjaran/RSUP Dr. Hasan Sadikin, Bandung, ${ }^{3}$ Departemen Ilmu Kesehatan Masyarakat, \\ Fakultas Kedokteran, Universitas Padjadjaran, Bandung
}

\begin{abstract}
Abstrak
Perbaikan kualitas pelayanan kesehatan di rumah sakit perlu dilakukan secara berkesinambungan. Pengukuran kualitas pelayanan kesehatan dapat dilakukan melalui beberapa pendekatan, di antaranya berdasar atas harapan pasien. Dengan menggali harapan pasien, aspek pelayanan kesehatan yang dianggap penting bagi pasien dapat dipahami oleh penyedia layanan. Pada era Jaminan Kesehatan Nasional (JKN), di Indonesia belum terdapat instrumen pengukur kualitas pelayanan berdasar atas harapan pasien sehingga peneliti bermaksud menyusun instrumen untuk mengukur kualitas pelayanan kesehatan berdasar atas harapan pasien. Penelitian ini merupakan penelitian kuantitatif dengan desain cross-sectional yang dilakukan terhadap 39 peserta JKN di Instalasi Rawat Jalan, RSUD Al-Ihsan, Kabupaten Bandung pada November 2016-Januari 2017. Pasien peserta JKN yang berobat rawat jalan lebih dari satu kali, dapat berkomunikasi dengan bahasa Indonesia, dan berpendidikan minimal SMA atau sederajat dilibatkan menjadi responden dalam penelitian ini. Data diperoleh melalui wawancara menggunakan instrumen yang disusun dari penelitian kualitatif mengenai kualitas pelayanan berdasar atas harapan pasien. Data yang diperoleh merupakan data ordinal yang merupakan tingkatan harapan pasien. Metode analisis yang digunakan untuk uji validitas dan reliabilitas adalah analisis pemodelan Rasch. Diperoleh instrumen pengukur kualitas pelayanan kesehatan berdasar atas harapan pasien yang terdiri atas 11 aspek, yakni sarana prasarana, karyawan, pelayanan medik, pelayanan administrasi, keamanan, kepercayaan, akses, transparansi informasi, kesetaraan, iur biaya, dan kualitas antarbagian. Nilai reliabilitas instrumen 0,92 dan alfa Cronbach 0,94. Terdapat 43 butir pertanyaan yang memiliki nilai outfit mean square di antara +2,0 dan +o,5; nilai outfit $z$-standard di antara +2,0 dan -2,0; serta nilai point measure correlation yang positif. Simpulan, diperoleh instrumen pengukur kualitas pelayanan kesehatan berdasar atas harapan pasien JKN yang valid dan reliabel, terdiri atas 11 aspek dan 43 butir pertanyaan.
\end{abstract}

Kata kunci: Harapan pasien, instrumen kualitas pelayanan, Jaminan Kesehatan Nasional

\section{Development of A Health Care Quality Instrument based on National Health Insurance Participant's Expectation at Hospital}

\begin{abstract}
Improving healthcare quality at the hospital should be done continually. Quality of healthcare can be evaluated using some methods, one of them is measuring patient's expectation. Exploring patient's expectation describes important aspects of healthcare that should be understood by healthcare provider. In this era of the National Health Insurance, in Indonesia there's still no health care quality instrument available yet, especially based on patients' expectation. The author aimed to develop an instrument measuring quality of health care based on patient's expectation at hospital. A qualitative study designed by cross-sectional was conducted to 39 participants of National Health Insurance at Outpatient Installation of Al-Ihsan Bandung District Hospital in November 2016-January 2017. National Health Insurance participants who had treatment more than once, could speak Indonesian fluently, and graduated from senior high school were involved in this study. The data was obtained by an interview using an instrument which was developed from a qualitative study. The data was an ordial scale measurement describing level of patient expectation. The method to analyze validity and reliability of the instrument was the Rasch model. Instrument measuring health care quality based on patient expectation consists of 11 aspects, those are facility and infrastructure, hospital staff, medical service, administrative service, safety, trustworthiness, access, transparacy of information, equality, cost sharing, and interdepartment quality. The reliability index of the instrument was 0.92 and Cronbach's alpha index was 0.94 . There were 45 items which have outfit mean square index between +2.0 and +0.5 , outfit z-standard index between +2.0 and -2.0 , and positive point measure correlation index. In conclusion, the instrument measuring quality of health care based on patient's expectation is valid and reliable, contains 11 dimensions and 43 items.
\end{abstract}

Key words: National Health Insurance, patient expectation, service quality instrument

Korespondensi: Ida Hadiyati, dr., MM-BAT. Dinas Kesehatan Kabupaten Bandung. Jln. Raya Soreang, Komplek Pemda Kabupaten Bandung. 40911. HP: +628122372579. E-mail: ida.hadiyati@ymail.com 


\section{Pendahuluan}

Konsep kualitas pelayanan kesehatan rumah sakit akan bervariasi di setiap tempat sepanjang waktu. ${ }^{1}$ Pelayanan yang berkualitas merupakan pelayanan yang unggul dan dapat memenuhi keinginan serta kebutuhan penerima pelayanan tersebut. ${ }^{2}$ Pengertian tentang kualitas pelayanan itu sendiri tentunya bervariasi dari berbagai macam perspektif. ${ }^{3}$ Begitu pula dengan dimensi kualitas juga bervariasi sesuai dengan kondisi tempat penyedia layanan tersebut berlangsung. ${ }^{4}$ Penyediaan pelayanan kesehatan rumah sakit yang berkualitas tidak terlepas dari perbaikan pelayanan kesehatan tersebut. Penilaian kualitas pelayanan kesehatan merupakan langkah yang penting dalam perbaikan kualitas pelayanan kesehatan rumah sakit. Berbagai teknik dapat dilaksanakan untuk menilai kualitas pelayanan kesehatan itu, di antaranya melalui pengukuran struktur, proses, hasil, dan penilaian dari sudut pandang pasien. Pengukuran struktur menilai karakteristik bermacam infrastuktur itu seperti fasilitas, karyawan, peraturan terkait pelayanan, dan juga ketersediaan sumber daya. Pengukuran struktur pun menilai perencanaan kesehatan. Walaupun pengukuran struktur menyediakan informasi penting mengenai kualitas pelayanan kesehatan, pengukuran ini tidak menilai performa pelayanan kesehatan maupun perbaikan derajat kesehatan pasien. Pengukuran proses penilaian penyedia layanan yang akan memberi pelayanan sesuai dengan standar operasional prosedur secara konsisten. Akan tetapi, pengukuran proses ini cukup sulit karena untuk menilai pelayanan yang diberikan sesuai prosedur secara konsisten tidak mudah. Selain itu, penilaian proses belum tentu dapat memprediksi hasilnya. Pengukuran hasil menilai derajat kesehatan pasien sebagai manifestasi dari pelayanan kesehatan yang diterima oleh pasien. Lebih spesifik, pengukuran ini menilai efek pelayanan kesehatan terhadap status kesehatan. Pengukuran ini juga menilai keberhasilan pelayanan kesehatan. Walaupun pengukuran ini sangat berguna, pengukuran ini cukup sulit untuk dilakukan di antaranya akibat sulit untuk mengumpullkan informasi riwayat medis yang lengkap. Selain itu, memperoleh informasi mengenai penilaian hasil itu sendiri pun cukup sulit. Terdapat hal selain pelayanan kesehatan yang terlibat dalam status kesehatan pasien, di antaranya keadaan lingkungan sosial dan ekonomi pasien juga cukup berpengaruh terhadap status kesehatan pasien. Pengukuran dari sudut pandang pasien dapat menyediakan masukan mengenai bagaimanakah pengalaman mereka untuk memperoleh pelayanan kesehatan. Pengukuran ini dapat memberikan gambaran mengenai berbagai aspek pelayanan kesehatan. ${ }^{5}$ Beberapa penelitian menunjukkan pengalaman pasien yang positif ternyata berhubungan dengan kualitas pelayanan kesehatan. ${ }^{6}$ Beberapa ahli menyarankan pengukuran melalui sudut pandang pasien ini untuk mengukur kualitas pelayanan kesehatan karena selain pengukurannya mudah dilakukan, aspek yang dapat dinilai pun luas. ${ }^{5}$

Untuk dapat menyediakan akses pelayanan kesehatan komprehensif bagi seluruh masyarakat Indonesia maka pemerintah membentuk program Jaminan Kesehatan Nasional (JKN). Akan tetapi, terdapat penurunan kepuasan pasien rawat jalan pada masa JKN bila dibandingkan dengan masa Askes. ${ }^{7}$ Dengan memahami harapan pasien maka penyedia layanan maupun pembuat kebijakan dapat memperoleh masukan dalam perbaikan kualitas pelayanan kesehatan itu. Memahami harapan pasien tentu juga dapat meningkatkan rasa nyaman ketika pasien berobat, kepercayaan terhadap pelayanan kesehatan, juga kepatuhan dalam pengobatan, dan memperpendek masa penyembuhan. ${ }^{8}$ Diharapkan dengan peningkatan kepercayaan pasien-pasien terhadap pelayanan kesehatan, tujuan pemerintah untuk mencapai cakupan program jaminan kesehatan semesta bagi seluruh masyarakat dapat tercapai sehingga keberlangsungan dan keberhasilan program JKN pun dapat tercapai.

Beberapa instrumen untuk dapat mengukur kualitas pelayanan kesehatan rumah sakit sudah dikembangkan di negara lain..$^{9-11}$ Akan tetapi, perbedaan budaya dan kondisi sosial berpengaruh terhadap harapan pasien mengenai kualitas pelayanan kesehatan itu. ${ }^{12}$ Di Indonesia pada sistem JKN belum terdapat instrumen pengukur kualitas pelayanan kesehatan yang sesuai dengan harapan pasien. Penelitian ini dilaksanakan bertujuan untuk menyusun instrumen pengukur kualitas pelayanan kesehatan berdasarkan atas harapan pasien peserta JKN di rumah sakit.

\section{Metode}

Penelitian ini dilaksanakan di Instalasi Rawat Jalan, Rumah Sakit Umum Daerah Al-Ihsan dan Rumah Sakit Umum Daerah Soreang, Kabupaten Bandung selama November 2016-Januari 2017. Peserta JKN yang berobat rawat jalan lebih dari satu kali, dapat berkomunikasi dengan bahasa 
Indonesia, dan berpendidikan minimal SMA atau sederajat dilibatkan menjadi responden. Sampel diperoleh mempergunakan teknik consecutive sampling sehingga populasi yang memenuhi kriteria inklusi memiliki kesempatan yang sama untuk dijadikan sebagai sampel penelitian. ${ }^{13}$ Responden yang sudah bersedia terlibat dalam penelitian diwawancarai untuk mengungkapkan tingkatan harapannya terhadap tiap-tiap butir pertanyaan dalam instrumen. Wawancara itu dilakukan oleh peneliti dan asisten peneliti yang telah diberi latihan sebelumnya. Wawancara itu memerlukan waktu 10-15 menit. Penelitian ini telah melalui perizinan Komisi Etik Penelitian Kesehatan, Fakultas Kedokteran, Universitas Padjadjaran dengan Nomor 835/UN6.C1.3.2/ KEPK/PN/2016.

Penelitianinimerupakan penelitian kuantitatif dengan desain cross-sectional yang merupakan tahapan uji rintis dalam proses pengembangan instrumen. Instrumen dikembangkan dari hasil penelitian kualitatif mengenai harapan pasien terhadap kualitas pelayanan kesehatan terhadap populasi yang sama. Instrumen ini mengukur 11 aspek pelayanan kesehatan rumah sakit, yakni sarana prasarana, karyawan, pelayanan medik, juga pelayanan administrasi, keamanan, kepercayaan, akses, transparansi informasi, kesetaraan, iur biaya, dan kualitas antarbagian. Instrumen menilai tingkatan harapan pasien terhadap pelayanan kesehatan rumah sakit. Alur penyusunan instrumen tercantum pada Gambar 1 sebagai berikut.

Reliabilitas dan validitas instrumen dianalisis mempergunakan pemodelan Rasch. Pemodelan Rasch mampu mentransformasi data ordinal yang dihasilkan dari instrumen menjadi data rasio sehingga akurat untuk dilakukan analisis. Reliabilitas dianalisis melalui nilai reliabilitas intrumen dan juga alfa Cronbach. Validitas isi ditunjukkan dengan analisis nilai fit statistics pada tiap-tiap butir pertanyaan, yakni nilai outfit mean square di antara $+2,0$ dan $+0,5$; nilai outfit $z$-standard di antara $+2,0$ dan $-2,0$; serta nilai point measure correlation yang positif. Validitas konstruksi tampak dari analisis

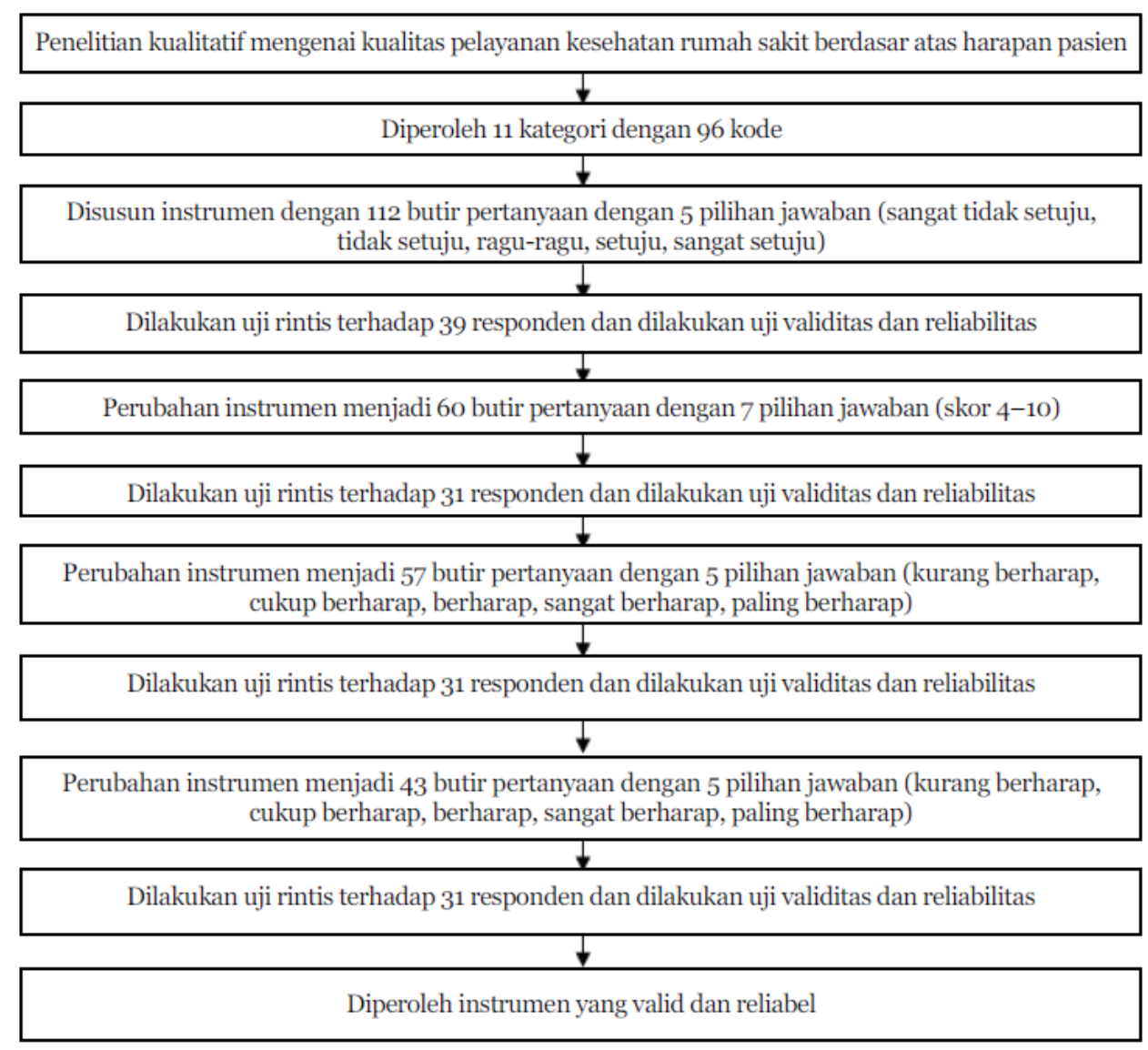

Gambar 1 Alur Penyusunan Instrumen

Global Medical and Health Communication, Vol. 5 No. 2 Tahun 2017 
item dimensionality melalui raw variance explained by measure yang lebih dari $20 \%$ dan unexplained variance yang kurang dari $15 \%$. Hal ini menunjukkan unidimensionalitas instrumen. Selain itu, dilakukan pula analisis pilihan jawaban yang ditunjukkan dari kurva probabilitas kategori yang terpisah-pisah setiap peringkat. Hal ini menunjukkan bahwa responden mengerti dan dapat membedakan tiap-tiap pilihan jawaban yang disajikan untuk menjawab setiap butir pertanyaan. ${ }^{14,15}$

\section{Hasil}

Terdapat 11 aspek kualitas pelayanan kesehatan rumah sakit yang dianalisis mempergunakan instrumen ini. Aspek tersebut meliputi sarana prasarana, karyawan, pelayanan medik, juga pelayanan administrasi, keamanan, kepercayaan, akses, transparansi informasi, kesetaraan, iur biaya, serta kualitas antarbagian. Analisis terhadap 112 butir pertanyaan menunjukkan nilai reliabilitas instrumen sangat buruk, yakni sebesar 0,14. Namun, nilai alfa Cronbach sangat baik, yakni sebesar 0,94. Analisis pada nilai outfit mean square, outfit $\mathrm{z}$-standard, dan point measure correlation pada setiap butir pertanyaan menunjukkan 52 butir pertanyaan tidak valid sehingga butir-butir tersebut dibuang. Nilai raw variance explained by measure sebesar $16,4 \%$ dan nilai unexplained variance sebesar $15,0 \%$. Keadaan ini menunjukkan bahwa instrumen belum bersifat unidimensi. Kurva probabilitas kategori yang tampak pada Gambar
2 menunjukkan bahwa tidak ada responden yang memilih peringkat 1 , yakni "sangat tidak setuju" sehingga kurva probabilitas kategori hanya terdiri atas 4 kurva. Selain itu, kurva "ragu" memiliki probabilitas yang lebih rendah dibanding dengan "tidak setuju" dan "setuju". Hal ini menunjukkan pilihan "ragu" bermakna rancu.

Analisis terhadap 60 butir pertanyaan itu menunjukkan nilai reliabilitas instrumen masih tergolong kategori cukup, yakni sebesar 0,77. Nilai alfa Cronbach sangat baik, yakni sebesar 0,95. Nilai outfit mean square, outfit z-standard, dan point measure correlation menunjukkan masih terdapat butir pertanyaan yang tidak valid sebanyak 3 butir dan butir-butir tersebut lalu dibuang. Nilai raw variance explained by measure meningkat menjadi $35,5 \%$ dan nilai unexplained variance menurun menjadi $11,7 \%$. Pilihan jawaban pada instrumen dengan 60 butir pertanyaan ini dibuat antara peringkat 4 hingga 10. Kurva probabilitas kategori yang terlampir pada Gambar 3 menunjukkan bahwa jarak kurva antarperingkat berdekatan. Dikhawatirkan dapat terjadinya kesalahan pemaknaan antarperingkat yang berdekatan oleh responden.

Analisis 57 butir pertanyaan menunjukkan nilai reliabilitas instrumen meningkat menjadi o,84. Nilai tersebut tergolong dalam kategori baik. Nilai alfa Cronbach menunjukkan nilai yang tergolong baik sekali sebesar 0,92. Akan tetapi, pada analisis nilai outfit mean square, outfit z-standard, dan point measure correlation masih terdapat 14 butir pertanyaan yang tidak valid. Nilai raw variance explained by measure

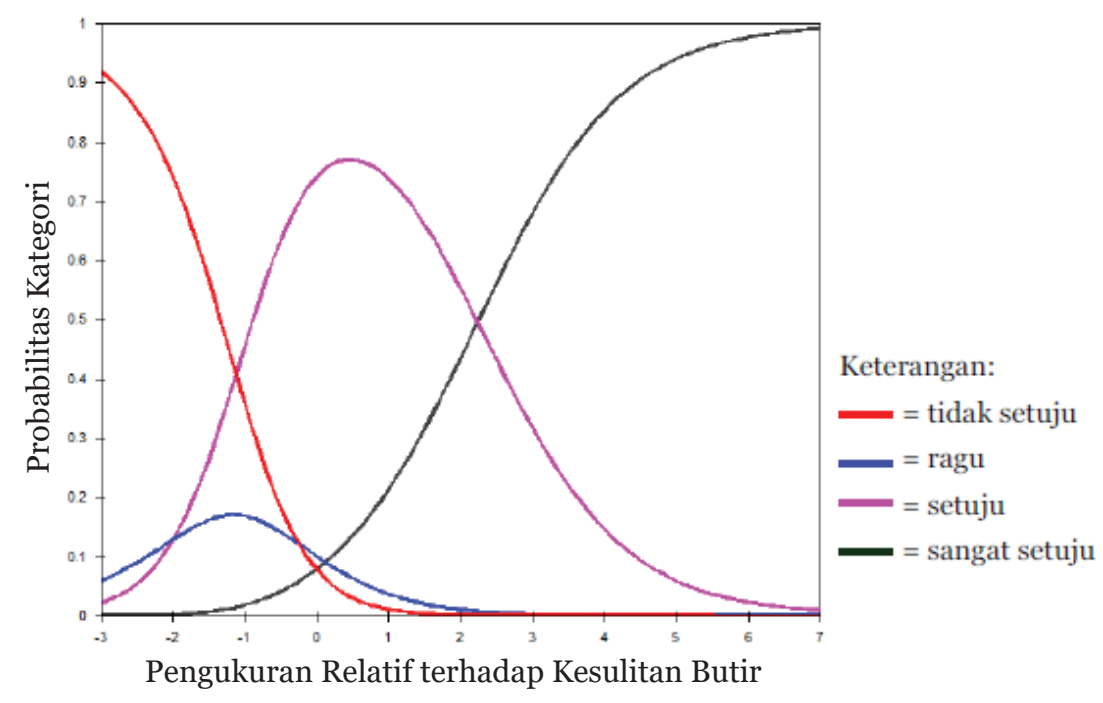

Gambar 2 Kurva Probabilitas Kategori 5 Pilihan Jawaban Sangat tidak setuju, tidak setuju, ragu, setuju, sangat setuju 


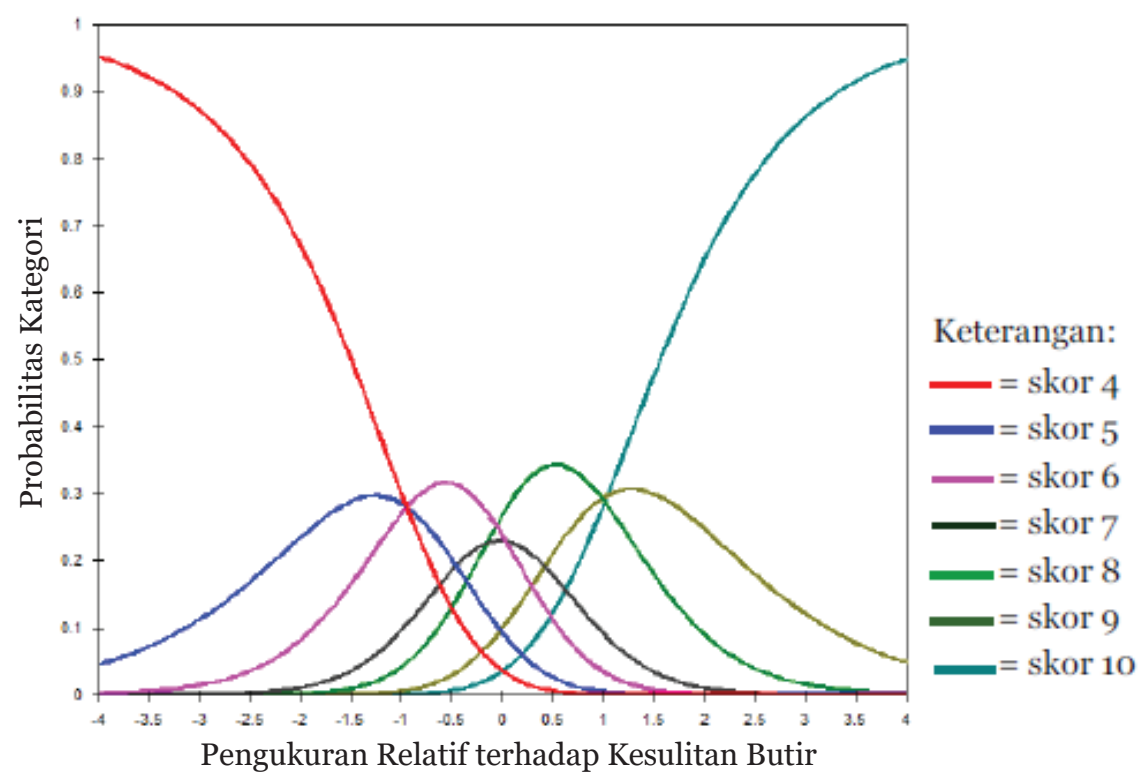

Gambar 3 Kurva Probabilitas Kategori 7 Pilihan Jawaban

sebesar 33,2\% dan unexplained variance 8,0\%. Kurva probabilitas kategori yang terlampir pada Gambar 4 menunjukkan kurva tiap-tiap pilihan jawaban terpisah dengan jarak antarkurva yang jelas. Hal ini menunjukkan bahwa pilihanjawaban dapat mewakili opini harapan responden.

Analisis 43 butir pertanyaan menunjukkan nilai reliabilitas instrumen meningkat menjadi o,85. Nilai alfa Cronbach meningkat baik sekali dengan nilai sebesar 0,94 . Nilai raw variance explained by measure meningkat menjadi $38,2 \%$ dengan nilai unexplained variance menurun menjadi $7,8 \%$. Nilai outfit mean square, outfit z-standard, dan point measure correlation menunjukkan tidak terdapat lagi butir yang tidak valid. Nilai tersebut ditunjukkan pada Tabel.

\section{Pembahasan}

Berdasar atas ekpektasi pasien peserta JKN, kualitas pelayanan kesehatan ini membutuhkan sarana prasarana dan karyawan yang memadai baik dari segi kuantitas maupun kualitasnya. Pelayanan kesehatan yang berkualitas perlu

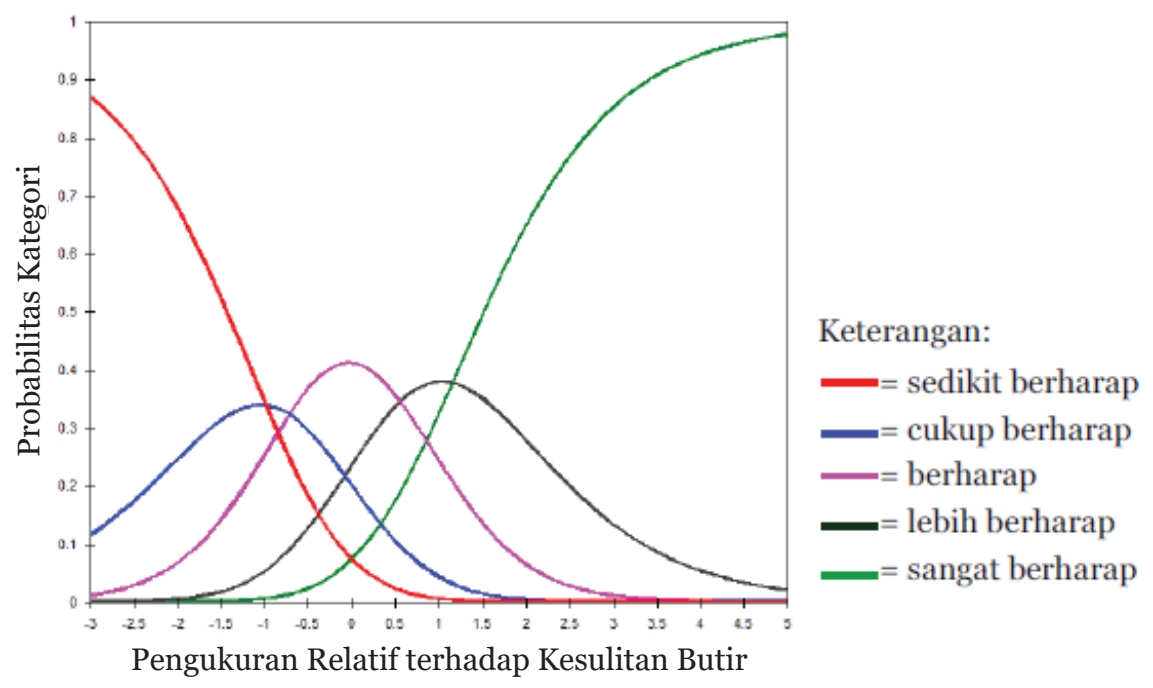

Gambar 4 Kurva Probabilitas Kategori 5 Pilihan Jawaban

Sedikit berharap, cukup berharap, berharap, lebih berharap, sangat berharap 


\section{Tabel Analisis Validitas Instrumen dengan 43 Butir Pertanyaan}

\begin{tabular}{|c|c|c|c|c|}
\hline $\begin{array}{l}\text { Kode } \\
\text { Butir }\end{array}$ & Butir Pertanyaan & MNSQ & ZSTD & $\begin{array}{c}\text { Pt. } \\
\text { Measure } \\
\text { Corr. }\end{array}$ \\
\hline \multicolumn{5}{|c|}{ Sarana Prasarana } \\
\hline A1 & Saya berharap terlihat ada petugas kebersihan yang selalu membersihkan ruangan. & 1,03 & 0,2 & 0,67 \\
\hline A2 & $\begin{array}{l}\text { Saya berharap obat-obatan yang saya butuhkan semuanya tersedia di apotek rumah sakit } \\
\text { sehingga tidak perlu membeli di apotek luar. }\end{array}$ & 0,82 & $-0,6$ & 0,73 \\
\hline A3 & Saya berharap peralatan untuk pemeriksaan di rumah sakit lengkap. & 1,44 & 1,4 & 0,24 \\
\hline A4 & $\begin{array}{l}\text { Saya berharap jumlah kursi di ruang tunggu cukup menampung pasien dan pengantar } \\
\text { pasien. }\end{array}$ & 1,12 & 0,5 & 0,41 \\
\hline A5 & $\begin{array}{l}\text { Saya berharap jumlah kamar mandi di rumah sakit sesuai perbandingannya dengan } \\
\text { banyaknya kunjungan pasien. }\end{array}$ & 1,11 & 0,5 & 0,50 \\
\hline A6 & $\begin{array}{l}\text { Saya berharap terdapat alat untuk penyuluhan tentang penyakit (berupa selembaran/media } \\
\text { suara/video). }\end{array}$ & 0,65 & $-1,6$ & 0,73 \\
\hline \multicolumn{5}{|c|}{ Karyawan } \\
\hline B1 & Saya berharap jumlah karyawan dan tenaga kesehatan sebanding dengan banyaknya pasien. & 0,83 & $-0,6$ & 0,65 \\
\hline B2 & Saya berharap karyawan dan tenaga kesehatan melayani dengan terampil. & 1,64 & 1,9 & 0,40 \\
\hline B3 & $\begin{array}{l}\text { Saya berharap dokter tepat dalam menemukan penyakit saya dan tepat dalam memberikan } \\
\text { terapi. }\end{array}$ & 1,41 & 1,7 & 0,38 \\
\hline B4 & Saya berharap setiap karyawan ramah dan penuh perhatian. & 0,97 & 0,0 & 0,44 \\
\hline $\mathrm{B} 5$ & Saya berharap setiap karyawan sigap dan cepat tanggap. & 1,37 & 1,2 & 0,33 \\
\hline \multicolumn{5}{|c|}{ Pelayanan Medis } \\
\hline $\mathrm{C} 1$ & Saya berharap dokter menjelaskan dengan jelas mengenai penyakit saya. & 0,89 & $-0,4$ & 0,36 \\
\hline $\mathrm{C} 2$ & $\begin{array}{l}\text { Saya berharap dokter menjelaskan dengan jelas tentang tindakan yang akan dilakukan dan } \\
\text { risiko yang mungkin terjadi. }\end{array}$ & 1,12 & 0,5 & 0,53 \\
\hline $\mathrm{C}_{3}$ & $\begin{array}{l}\text { Saya berharap tenaga kesehatan menjelaskan cara penanganan dan pencegahan penyakit } \\
\text { saya di rumah. }\end{array}$ & 1,37 & 1,3 & 0,23 \\
\hline $\mathrm{C}_{4}$ & $\begin{array}{l}\text { Saya berharap petugas obat menjelaskan dengan jelas mengenai cara minum obat atau } \\
\text { pemakaian obat. }\end{array}$ & 1,24 & 0,9 & 0,48 \\
\hline \multicolumn{5}{|c|}{ Pelayanan Administrasi } \\
\hline D1 & Saya berharap waktu tunggu pasien untuk dilayani tidak lama. & 0,76 & $-0,9$ & 0,38 \\
\hline D2 & Saya berharap pelayanan dimulai sesuai jadwal. & 1,01 & 0,2 & 0,19 \\
\hline D3 & $\begin{array}{l}\text { Saya berharap ada petugas yang menjaga pengambilan nomor antrean sehingga tidak ada } \\
\text { tindakan curang. }\end{array}$ & 1,02 & 0,2 & 0,51 \\
\hline \multicolumn{5}{|c|}{ Keamanan dalam Pelayanan } \\
\hline $\mathrm{E} 1$ & Saya berharap peralatan untuk pelayanan dan tindakan higienis. & 0,89 & $-0,3$ & 0,69 \\
\hline \multicolumn{5}{|c|}{ Sarana Prasarana } \\
\hline E2 & Saya berharap merasa aman ketika diperiksa dan dilakukan tindakan. & 1,32 & 1,2 & 0,66 \\
\hline $\mathrm{E}_{3}$ & Saya berharap mendapat obat-obatan yang berkualitas dan aman bagi pasien. & 0,84 & $-0,6$ & 0,65 \\
\hline \multicolumn{5}{|c|}{ Kepercayaan terhadap Rumah Sakit } \\
\hline $\mathrm{F} 1$ & Saya berharap merasa nyaman berobat di rumah sakit ini. & 0,81 & $-0,6$ & 0,63 \\
\hline $\mathrm{F} 2$ & Saya berharap penyakit saya membaik setelah diobati. & 1,06 & 0,3 & 0,44 \\
\hline F3 & Saya berharap kualitas hidup saya membaik setelah diobati. & 0,83 & $-0,7$ & 0,80 \\
\hline \multicolumn{5}{|l|}{ Akses } \\
\hline G1 & Saya berharap lokasi rumah sakit mudah dijangkau dengan transportasi umum. & 1,27 & 1,2 & 0,58 \\
\hline G2 & Saya berharap jalan di depan rumah sakit cukup lebar untuk dilalui kendaraan dua arah. & 0,89 & $-0,4$ & 0,47 \\
\hline G3 & Saya berharap lokasi rumah sakit dapat dijangkau dengan cepat dan tidak macet. & 1,10 & 0,4 & 0,15 \\
\hline \multicolumn{5}{|c|}{ Transparansi Informasi } \\
\hline H1 & $\begin{array}{l}\text { Saya berharap terpampang daftar tunggu pasien yang membutuhkan rawat inap yang belum } \\
\text { mendapat ruangan. }\end{array}$ & 1,00 & 0,1 & 0,67 \\
\hline $\mathrm{H} 2$ & Saya berharap terpampang jadwal daftar tunggu pasien yang membutuhkan operasi. & 1,10 & 0,5 & 0,27 \\
\hline $\mathrm{H} 3$ & Saya berharap terpampang jadwal pelayanan dokter dengan jelas. & 0,99 & 0,1 & 0,67 \\
\hline $\mathrm{H}_{4}$ & Saya berharap terpampang persyaratan administrasi dengan jelas. & 0,69 & $-1,3$ & 0,49 \\
\hline $\mathrm{H}_{5}$ & $\begin{array}{l}\text { Saya berharap terpampang kebijakan Badan Penyelenggara Jaminan Sosial (BPJS) tentang } \\
\text { hak dan kewajiban pasien. }\end{array}$ & 0,84 & $-0,6$ & 0,67 \\
\hline \multicolumn{5}{|c|}{ Kesetaraan } \\
\hline I1 & Saya berharap sebagai peserta JKN dilayani dengan teliti sama seperti pasien umum. & 1,06 & 0,4 & 0,55 \\
\hline I2 & Saya berharap sebagai peserta JKN dilayani dengan cepat sama seperti pasien umum. & 0,66 & $-1,5$ & 0,59 \\
\hline I3 & Saya berharap sebagai peserta JKN diperlakukan ramah sama seperti pasien umum. & 0,67 & $-1,5$ & 0,57 \\
\hline I4 & $\begin{array}{l}\text { Saya berharap tidak ada perbedaan jatah rawat inap antara saya sebagai peserta JKN dan } \\
\text { pasien umum. }\end{array}$ & 0,73 & $-1,1$ & 0,56 \\
\hline \multicolumn{5}{|c|}{ Iur Biaya } \\
\hline $\mathrm{J}_{1}$ & $\begin{array}{l}\text { Saya berharap sebagai peserta JKN tidak perlu mengeluarkan biaya tambahan untuk } \\
\text { tindakan medis (operasi, dll.). }\end{array}$ & 0,89 & $-0,2$ & 0,39 \\
\hline J2 & $\begin{array}{l}\text { Saya berharap sebagai peserta JKN tidak perlu mengeluarkan biaya tambahan untuk } \\
\text { pemeriksaan penunjang (pemeriksaan laboratorium, rontgen, dll.). }\end{array}$ & 1,11 & 0,4 & 0,39 \\
\hline $\mathrm{J}_{3}$ & $\begin{array}{l}\text { Saya berharap sebagai peserta JKN tidak perlu mengeluarkan biaya tambahan untuk } \\
\text { membeli obat-obatan di luar apotek rumah sakit. }\end{array}$ & 1,17 & 0,6 & 0,35 \\
\hline $\mathrm{J}_{4}$ & $\begin{array}{l}\text { Saya berharap sebagai peserta JKN tidak perlu mengeluarkan biaya tambahan untuk rawat } \\
\text { inap. }\end{array}$ & 0,97 & 0,0 & 0,46 \\
\hline \multicolumn{5}{|c|}{ Kualitas Antarbagian } \\
\hline K1 & Saya berharap semua petugas cepat tanggap dalam melayani pasien. & 0,85 & $-0,6$ & 0,46 \\
\hline $\mathrm{K} 2$ & Saya berharap semua petugas bersikap ramah di setiap pelayanan. & 1,39 & 1,6 & 0,52 \\
\hline $\mathrm{K}_{3}$ & Saya berharap seluruh ruangan tampak bersih. & 1,32 & 1,2 & 0,20 \\
\hline
\end{tabular}

Keterangan: MNSQ=meansquare outfit, ZSTD=Z-standard outfit; Pt. Measure Corr.=point measure correlation 
memperhatikan pada pelayanan medik maupun pelayanan administrasi. Dengan demikian maka pelayanan tentang tersebut perlu memperhatikan keamanan, kepercayaan, dan juga transparansi informasi. Akses juga perlu diperhatikan untuk mencapai pelayanan kesehatan. Keseluruhan proses tersebut harus memenuhi kualitas secara komprehensif sehingga membutuhkan kualitas antarbagian. Diperoleh dimensi yang baru dalam instrumen ini yang sesuai pada era $\mathrm{JKN}$, yakni kesetaraan dan iur biaya.

Pada penelitian yang lainnya, sarana serta prasarana diungkapkan sebagai dimensi yang menggambarkan keadaan fisik fasilitas pelayanan kesehatan, misalnya desain bangunan. ${ }^{16,17}$ Pada penelitian ini, pasien mementingkan hal yang lain dibanding dengan estetika. Sarana prasarana diungkapkan sebagai kelengkapan, kapasitas, dan kebersihan dari fasilitas pelayanan. Kelengkapan peralatan kesehatan maupun obat-obatan yang tersedia di rumah sakit diharapkan oleh pasien. Tersedianya media untuk penyuluhan mengenai penyakit untuk menambah wawasan kesehatan bagi pasien juga merupakan salah satu bentuk kelengkapan fasilitas itu. Tidak hanya tersedia, kapasitas fasilitas yang tersedia pun harus sesuai dengan banyaknya kunjungan ke rumah sakit, di antaranya seperti jumlah kursi di ruang tunggu dan jumlah kamar mandi yang sesuai dengan banyaknya pengunjung. Di samping itu, seperti halnya pada penelitian lain, kebersihan fasilitas dan perlengkapan juga menjadi perhatian. ${ }^{10,18}$ Pada penelitian ini kebersihan ditandai dengan terdapatnya petugas yang selalu membersihkan ruangan.

Karyawan ialah dimensi yang menggambarkan kualitas tenaga kerja beserta kuantitasnya. Tenaga kerja meliputi tenaga kesehatan maupun tenaga kerja administrasi dan tenaga penunjang lainnya. Seperti halnya penelitian lain, kualitas yang diharapkan meliputi keandalan, ketanggapan, keramahan, dan perhatian. Keandalan meliputi kompetensi dan keterampilan yang menyebabkan pasien akan merasa terjamin untuk dilayani oleh petugas. Ketanggapan meliputi kesigapan dan kecepatan petugas dalam menanggapi keluhan pasien. Keramahan dan perhatian menunjukkan terdapat rasa empati petugas terhadap pasien. ${ }^{18,19}$ Pada penelitian ini, dimensi karyawan selain menggambarkan kualitas juga menggambarkan kuantitas tenaga kerja. Pada era JKN ini terjadi peningkatan kunjungan pasien berobat sehingga kapasitas tenaga kerja juga perlu disesuaikan jumlahnya. Dengan peningkatan jumlah pekerja yang juga sebanding dengan kunjungan pasien diharapkan pelayanan dapat berlangsung efektif dan efisien.

Pelayanan medik adalah inti proses pelayanan kesehatan. Penelitian lain menyatakan bahwa dimensi ini sulit untuk dievaluasi oleh pasien karenapasien memilikipengetahuanyangterbatas mengenai hal dimensi ini. ${ }^{10}$ Pada penelitian ini, dimensi pelayanan medik digambarkan sebagai komunikasi mengenai kesehatan oleh tenaga medik. Komunikasi tersebut berupa penjelasan mengenai penyakit pasien, tindakan yang akan dilakukan beserta risiko yang mungkin terjadi, cara penanganan dan pencegahan penyakit di rumah, serta cara minum obat atau pemakaian obat merupakan keadaan yang diperhatikan oleh pasien. Pasien menilai pemberian penjelasan menunjukkan bahwa tenaga medik memahami keluhan pasien dan menguasai ilmu mengenai penyakit tersebut.

Pelayanan administrasi itu mencakup rentang waktu selain pelayanan medik termasuk proses pendaftaran pasien. Seperti halnya penelitian lain, hal utama yang diperhatikan pada dimensi ini adalah waktu tunggu pasien untuk menerima pelayanan. ${ }^{20,21}$ Pada penelitian ini, kesesuaian jadwal pelayanan pun menjadi perhatian pada dimensi ini. Selain itu, pada proses pendaftaran keadaan yang diperhatikan adalah pengambilan nomor antrean. Pada era JKN, seiring dengan peningkatan kunjungan pasien, perlu ada petugas yang menjaga pengambilan nomor antrean agar tidak ada tindakan curang.

Keamanan merupakan hal yang penting dalam pelayanan kesehatan oleh karena setiap tindakan medik dapat memiliki risiko. ${ }^{10}$ Rasa aman dan terjamin dalam proses pemeriksaan dan tindakan menjadi hal yang diperhatikan pada dimensi ini. Selain itu, keamanan juga meliputi pemberian obat-obatan yang berkualitas dan aman seperti pemilihan obat yang tidak menyebabkan alergi terhadap pasien dan pemastian obat-obatan yang diberikan tidak kedaluwarsa. Selain dari tindakan medik, keamanan sarana pun dibutuhkan seperti lantai tidak licin dan terdapat pegangan di selasar untuk menuntun lanjut usia berjalan.

Kepercayaan terhadap rumah sakit menurut penelitian yang lain diungkapkan sebagai rasa nyaman serta sejahtera berada di rumah sakit. ${ }^{10}$ Pada penelitian ini, kepercayaan merupakan manifestasi hasil dari pelayanan kesehatan yang didapat oleh pasien. Kepercayaan timbul akibat 
perbaikan kondisi pasien dan juga peningkatan kualitas hidup pasien. Perbaikan kondisi pasien dari penyakit merupakan tujuan utama pasien mendapatkan pelayanan kesehatan sehingga hal tersebut dapat membentuk kepercayaan dan loyalitas terhadap rumah sakit.

Akses merupakan letak geografis dan jarak tempuh yang dibutuhkan untuk mencapai lokasi rumah sakit. Akses juga digambarkan sebagai kemampuan dan ketersediaan untuk menempuh pelayanan kesehatan itu. Di Indonesia masalah akses masih menjadi penghambat pasien untuk mendapatkan pelayanan kesehatan tersebut. ${ }^{22}$ Walaupun telah mempunyai jaminan kesehatan yang ditanggung oleh pemerintah, pasien yang berpenghasilan rendah juga masih tidak dapat mencapai fasilitas kesehatan itu dengan alasan keterbatasan pada akses. Walau akses bukan merupakan kebijakan pihak rumah sakit, namun akses tetap menjadi dimensi yang terkait dengan pelayanan kesehatan. Tanpa akses yang baik, masyarakat masih tetap tidak dapat memperoleh pelayanan kesehatan berkualitas. Setidaknya rumah sakit berlokasi di tempat yang terjangkau dengan transportasi umum. Selain itu, akses jalan di sekitar rumah sakit pun harus cukup lebar untuk dilalui kendaraan dua arah, untuk memudahkan akses pasien dalam gawat darurat. Beberapa penyebab kemacetan di sekitar rumah sakit di antaranya disebabkan oleh angkutan umum yang parkir berjajar di sepanjang pinggir jalan untuk mencari penumpang, kendaraan yang parkir di pinggir jalan, dan para pedagang yang berdagang di pinggir jalan. Perlu kerja sama lintas sektoral untuk menangani masalah akses

Transparansi informasi merupakan hal yang penting dalam pelayanan. Tanpa informasi yang jelas dapat terjadi spekulasi yang bervariasi dari subjektivitas tiap-tiap individu. Transparansi informasi di antaranya meliputi terpampangnya daftar tunggu pasien yang membutuhkan rawat inap dan operasi. Pada era JKN ini penggunaan fasilitas rawat inap dan operasi meningkat. Akibatnya banyak antrean yang membutuhkan fasilitas tersebut. Oleh karena itu, dibutuhkan daftar tunggu untuk menginformasikan antrean tersebut. Selain itu, informasi yang sebaiknya terpampang adalah jadwal pelayanan dokter dan persyaratan administrasi. Penelitian lain tidak banyak mengungkapkan dimensi ini. Salah satu penelitian yang telah mengungkapkannya berupa penjelasan secara tepat tentang prosedur rumah sakit. ${ }^{21}$
Kesetaraan merupakan salah satu dimensi yang perlu diperhatikan pada era JKN. Dalam hal ini, kesetaraan yang dimaksud adalah kesetaraan antara pasien pengguna $\mathrm{JKN}$ dan pasien yang tidak mempergunakan JKN. Keduanya harus diperlakukan dengan ketelitian, ketanggapan, dan keramahan yang sama. Selain itu, pasien juga berharap tidak diberlakukannya perbedaan jatah rawat inap untuk peserta JKN dengan pasien yang berbayar.

Iur biaya pun merupakan dimensi yang perlu diperhatikan pada era JKN. Terdapat dua jenis pengguna JKN, yakni pengguna yang menerima bantuan iuran setiap bulan dari pemerintah dan pengguna yang membayar iuran setiap bulan secara pribadi. Mereka berharap biaya tersebut sudah meliputi seluruh kebutuhan mediknya. Mereka berharap tidak ada penambahan biaya untuk tindakan medik, pemeriksaan penunjang, pembelian obat-obatan, atau pun rawat inap. Penambahan biaya dapat memberatkan, baik penerima bantuan iuran yang memang sudah jelas merupakan masyarakat yang kurang mampu maupun pengguna yang membayar iuran setiap bulan secara pribadi.

Untuk dapat menciptakan pelayanan yang berkualitas perlu kesinergian antara karyawan dan bekerja sama pada setiap titik pelayanan sehingga menghasilkan kualitas antara bagian. Sejak kedatangan pasien ke rumah sakit hingga kepulangannya, mulai dari proses pendaftaran, pemeriksaan kesehatan, hingga penerimaan obat di bagian farmasi diharapkan para petugasnya cepat tanggap dan juga ramah. Selain itu, seluruh fasilitas di bagian mana pun harus tampak bersih. Instrumen ini diharapkan mampu membantu penyedia pelayanan kesehatan rumah sakit untuk memahami harapan pasien dalam hal perbaikan kualitas pelayanan kesehatan rumah sakit.

\section{Simpulan}

Instrumen untuk mengukur kualitas pelayanan kesehatan berdasar atas harapan pasien peserta JKN di rumah sakit yang terdiri atas dimensi sarana prasarana, karyawan, pelayanan medis, pelayanan administrasi, juga keamanan dalam pelayanan, kepercayaan terhadap rumah sakit, akses, transparansi informasi, kesetaraan, iur biaya, serta termasuk kualitas antara bagian. Instrumen ini valid dan reliabel dapat digunakan dalam pengukuran kualitas pelayanan kesehatan berdasar atas harapan pasien. 


\section{Daftar Pustaka}

1. Yarimoglu EK. A review on dimensions of service quality models. J Mark Manage. 2014;2(2):79-93.

2. Omachonu VK, Einspruch NG. Innovation in healthcare delivery systems: a conceptual framework. Innov J: Public Sect Innov J. 2010;15(1):Article 2.

3. Buttell P, Hendler R, Daley J. Quality in healthcare: concepts and practice. Dalam: Cohn KH, Hough DE, penyunting. The business of healthcare. Volume 1: practice management business healthcare. Westport, Connecticut: Praeger Publishers; 2007. hlm. 61-94.

4. O'Donnell O. Access to health care in developing countries: breaking down demand side barriers. Cad Saude Publica. 2007;23(12):2820-34.

5. Zhao SH, Akkadechanunt T. Patients' perceptions of quality nursing care in a Chinese Hospital. Int $\mathrm{J}$ Nurs Midwifery. 2011;3(9):145-9.

6. Morris C, Bailey K. Measuring health care quality: an overview of quality measures. Families USA issue brief May 2014 [diunduh 13 Februari 2017]. Tersedia dari: http://familiesusa.org/sites/default/files/ product_documents/HSI\%20Quality\%2O Measurement_Brief_final_web.pdf.

7. Trisnawati K, Sumarni, Fudholi A. Analisis kepuasan pasien rawat jalan PNS pada masa pelaksanaan ASKES dan JKN. JMPF. 2015;5(1):33-9.

8. Schröder A, Larsson BW, Ahlström G. Quality in psychiatric care: an instrument evaluating patient's expectations and experiences. Int $J$ Health Care Qual Assur. 2007;20(2-3):14160.

9. Tahir M, Nawaz S, Butt MZ, Amin F, Mahmood KT. In-patient perceptions, needs, expectations, and satisfaction within tertiary care settings. J Pharm Sci Res. 2012;4(12):2025-31.

10. Padma P, Rajendran C, Lokachari PS. A conceptual framework of service quality in healthcare: perspective of Indian patients and their attendants. Benchmarking Int J.
2009;16(2):157-91.

11. Senarath U, Gunawardena NS. Development of an instrument to measure patient perception of the quality of nursing care and related hospital services at the National Hospital of Sri Lanka. Asian Nurs Res (Korean Soc Nurs Sci). 2011;5(2):71-80.

12. Pai YP, Chary ST. Dimensions of hospital service quality: a critical review, perspective of patients from global studies. Int $\mathrm{J}$ Health Care Qual Assur. 2013;26(4):308-40.

13. Omair A. Sample size estimation and sampling techniques for selecting a representative sample. J Health Spec. 2017;2(4):142-7.

14. Engelhard Jr. G. Invariant measurement: using Rasch models in the social, behavioral, and health sciences. New York: Routledge; 2013.

15. Sumintono B, Widhiarso W. Aplikasi Model Rasch untuk penelitian ilmu-ilmu sosial. Edisi ke-2. Cimahi: Trim Komunikata Publishing House; 2015.

16. Butt MM, deRun EC. Private healthcare quality: applying a SERVQUAL model. Int $J$ Health Care Qual Assur. 2010;23(7):668-73.

17. Al-Borie HM, Damanhouri AMS. Patients' satisfaction of service quality in Saudi Hospitals: a SERVQUAL analysis. Int $J$ Health Care Qual Assur. 2013;26(1):20-30.

18. Chaabouni S, Abednnadher C. The relationship between patient satisfaction and service quality: a study of hospitals in Tunisia. Indian J Health Wellbeing. 2014;5(3):330-4.

19. Arasli H, Ekiz EH, Katircioglu ST. Gearing service quality into public and private hospitals in small islands: empirical evidence from Cyprus. Int J Health Care Qual Assur. 2006;21(1):8-23.

20. Atinga RA. Healthcare Quality under the national health insurance scheme in Ghana. Int J Qual Reliability Manag. 2012;29(2):14461.

21. De Jager JW, du Plooy AT, Ayadi MF. Delivering quality service to in-and outpatients in a South African Public Hospital. African J Bus Manag. 2010;4(2):133-9.

22. Peraturan Presiden Republik Indonesia Nomor 72 Tahun 2012 tentang Sistem Kesehatan Nasional. 